Article

\title{
Forest Concessions and the United Nations Sustainable Development Goals: Potentials, Challenges and Ways Forward
}

\author{
Yitagesu Tekle Tegegne ${ }^{1, *}$, Mathias Cramm ${ }^{2}$, Jo Van Brusselen ${ }^{2}\left(\mathbb{D}\right.$ and Thais Linhares-Juvenal ${ }^{3}$ \\ 1 European Forest Institute, St. Leopold Pavilion, c/St. Antoni M. Claret, 167, 08025 Barcelona, Spain \\ 2 European Forest Institute, Yliopistokatu 6B, 80100 Joensuu, Finland; m.cramm@gmail.com (M.C.); \\ jo.vanbrusselen@efi.int (J.V.B.) \\ 3 Forestry Policy and Resources Division, FAO, Vialle Terme di Caracalla, 00153 Rome, Italy; \\ Thais.LinharesJuvenal@fao.org \\ * Correspondence: yitagesu.tekle@efi.int; Tel.: +34-667-527-202
}

Received: 16 November 2018; Accepted: 4 January 2019; Published: 10 January 2019

\begin{abstract}
The Agenda 2030 and its Sustainable Development Goals (SDGs) have directed increased political attention to forests and their sustainable management globally. Forest concessions are a predominant instrument for the sustainable management of public production natural forests in the tropics, but the relationship between the SDGs and forest concessions is poorly explored. Knowledge of this relationship could facilitate aligning tropical forest concession regimes with the SDGs. This research was conducted by means of an online survey, expert interviews and four regional stakeholder workshops to examine (i) how forest concessions can support the implementation of the SDGs; and (ii) what are the key barriers hindering the potential contributions of forest concessions to the SDG. The findings revealed three broad pathways through which forest concessions can support the implementation of the SDGs: (i) sustainable use and management of ecosystem goods and services as the core business; (ii) provision of public goods for socioeconomic development; and (iii) contribution to (sub) national economies through income, employment and fiscal obligations. The paper identifies region-specific (Africa, Latin America and Southeast Asia) technical, legal, governance and institutional barriers limiting the potential contributions. Among these, the key barriers are unclear and conflicting tenure, and the lack of available technical and qualified personnel. The paper concludes that the contributions of forest concessions to the SDGs depend on governance context and the clear use of the instrument to deliver such objectives as better planned and implemented concessions and binding concession contracts. The paper also provides recommendations for aligning forest concessions with the SDGs.
\end{abstract}

Keywords: forest concessions; SDGs; tropical forests; sustainable forest management

\section{Introduction}

Forest concessions are a policy instrument to implement forest harvesting, which can be effective in advancing sustainable forest management (SFM) in tropical public production forests if planned and implemented according to the best practices of environmental, social and economic sustainability. A forest concession is a widely used contractual arrangement, in which a government temporarily allocates some of its public forests to another party, such as a company. The contract typically includes use rights to specific resources in the area paired with obligations for their management [1]. Governments can opt for forest concessions to 'outsource' forest use and management due to their own lack of relevant capacities and expertise, as an instrument to secure access and use rights while keeping the forests public, or in combination with the previous options, as a vehicle to carry out SFM [1,2]. 
A recent assessment [3] indicates that there are at least 122 million ha of industrial forest concessions in West and Central Africa, Latin America and Southeast Asia, equivalent to 54\% of the public production forests in these areas. Due to the vast extent of these industrial forest concessions, their management has considerable implications for sustainable development, biodiversity conservation, climate change mitigation and adaptation, and the provision of ecosystem services and socioeconomic benefits from global forest resources [4-7].

Forest concessions have been examined from various angles, such as their economic viability [8-10], their environmental impacts [11-13], their relationship with local communities [14-16], and their governance [17-19]. Generally, the use of this instrument in the tropics has yielded mixed results. Forest concessions have improved the livelihoods of local communities [20], contributed to forest conservation [21], and helped build public infrastructure in remote areas [22], while in other cases, forests under concessions have become degraded [23], governments' financial expectations of forest concessions have been unmet [24], or forest concessions have contributed to tenure conflicts and insecurity [25].

Despite the global importance of the SDGs in framing policy and development, and although the understanding of the relationship between the SDGs and tropical forests and their management has been increasing $[6,26,27]$, there is no detailed analysis of the potential of tropical forest concessions in implementing the SDGs. Policy makers and other stakeholders could benefit from increased understanding of the linkages between SDGs and forest concessions. This could also increase awareness of the opportunities and challenges that the SDGs can provide for forest concessions and facilitate multi-stakeholder dialogue and collaboration towards implementation of the SDGs with the support of forest concessions. Knowledge is also lacking in terms of barriers that hinder forest concessions' contributions to the SDGs. Moreover, there have been no studies on forest concessions that comprise and compare the three tropical regions. Yet, comparative studies can help reveal presuppositions that would remain unobserved when focusing on one confined geography, and new suggestions coming from other regions may improve current explanations [28]. Furthermore, comparative examination can help capture both similarities and differences among the study objects and explain their reasons [29].

Therefore, focusing on all the tropical regions, this study asks: how can tropical countries align their forest concession regimes with the SDGs? This is further elucidated with two sub-research questions:

1. How can forest concessions support the implementation of the SDGs?

2. What barriers are hindering forest concessions' potential contributions to the SDGs, and what variation exists between the tropical regions?

The rest of the sections are organized as follows: Section 2 will introduce the SDGs and specify the concept of forest concession as used in this study. Section 3 presents the materials and methods used. This is followed by the results in Section 4 . Next, Section 5 discusses and analyzes the results. Finally, Section 6 draws conclusions and makes recommendations on how tropical countries can align their forest concession regimes with the SDGs.

\section{The United Nations Sustainable Development Goals (UN SDGs) and Forest Concessions}

In this section, we (i) introduce the United Nations SDGs, and (i) present forest concessions as conceptualized in this study. 


\subsection{United Nations Sustainable Development Goals}

In September 2015, the United Nations (UN) Sustainable Development Summit agreed upon a global framework for sustainable development. The framework is composed of 17 SDGs focusing on a broad range of issues, spanning from 'classical' development topics, such as poverty and food security, over economic development and infrastructure to environmental issues and climate change. The SDGs are in force until 2030 and they supersede the Millennium Development Goals that covered the period 2000-2015. The SDGs are composed of 169 targets and 241 indicators [30]. The SDGs provide the world's comprehensive plan of action for economic development, environmental sustainability, and social inclusion. Meeting the SDGs by 2030 requires substantial and ongoing cooperation and collaboration among all sectors and stakeholders (i.e., governments, private sector, communities and civil society). Table 1 presents an overall development indicator under each SDG for 24 forest-rich tropical countries by providing relevant data from the World Development Indicators.

\subsection{Forest Concessions as Conceptualized in This Study}

Governments have a range of policy instruments to implement sustainable forest management (SFM), forest concessions being one of them. In the present study, a forest concession is considered as a forest policy instrument for the sustainable management of tropical public production natural forests. There are at least 122 million ha of industrial forest concessions in the tropics, representing $54 \%$ of public production forests (Table 2). These figures show the potential of the use of forest concessions as a policy instrument to mainstream SFM over vast extent of tropical forests. The use of this instrument involves designing policy, legal and institutional frameworks that set the rules and procedures for the instrument's application, and mandate and capacitate public administration and relevant stakeholders to control the instrument [1]. A concession regime refers to 'the concession system as a whole in a country. It includes all the institutions, regulations and procedures involved in designing and administrating concessions' [31].

Beyond industrial forest concessions that are often understood as large-scale and company-owned and that are primarily associated with timber production [22], there are also forest concessions granted to communities or civil society organizations [20,32]. Forest concessions may have multiple objectives with different priorities related to management and production of timber and non-timber resources, and management and provision of various other ecosystem services, such as restoration or conservation [32-34]. This study adopts '(forest) concession' as a term for commercial forest concessions characterized by a long-term contract for management of the area and a primary focus on timber production. Moreover, the present study specifically considers forest concessions in public production natural forests and, thus, excludes concessions for plantations or land-use change. 
Table 1. Sustainable Development Goals (SDGs) and selected World Development Indicators for forest-rich tropical countries.

\begin{tabular}{|c|c|c|c|c|c|c|c|c|c|c|c|c|c|c|c|c|c|}
\hline Countries & SDG1 & SDG2 & SDG3 & SDG4 & SDG5 & SDG6 & SDG7 & SDG8 & SDG9 & SDG 10 & SDG 11 & SDG 12 & SDG13 & SDG14 & SDG15 & SDG16 & SDG17 \\
\hline \multicolumn{18}{|c|}{ Latin America } \\
\hline Bolivia & 7.1 & 27.2 & 206.0 & 88.5 & 4.0 & 75.6 & 71.5 & 3.5 & 31.0 & 3.5 & 43.5 & 3.5 & 2.3 & 0.0 & 50.6 & 3.0 & 39.7 \\
\hline Brazil & 4.3 & 7.1 & 44.0 & 92.7 & .. & 87.0 & 97.8 & 13.4 & 21.2 & .. & 22.3 & .. & 4.5 & 20.5 & 59.0 & .. & 59.7 \\
\hline Guatemala & 9.5 & 46.5 & 88.0 & 85.5 & & 86.8 & 74.8 & 2.6 & 27.5 & & 34.5 & & 3.3 & 13.0 & 33.0 & & 34.5 \\
\hline Guyana & 14.0 & 12.0 & 229.0 & 81.4 & 3.0 & 98.3 & 84.0 & 11.5 & 5.7 & 3.0 & 33.1 & 2.5 & .. & 0.2 & 84.0 & 3.0 & 35.7 \\
\hline Peru & 3.0 & 14.6 & 68.0 & 94.1 & .. & 69.2 & 74.5 & 6.8 & 32.5 & .. & 34.2 & .. & 3.0 & 6.8 & 57.8 & .. & 45.5 \\
\hline Suriname & 23.4 & 8.8 & 155.0 & 93.3 & .. & 88.4 & 96.8 & 8.9 & 32.0 &.. & 7.3 & .. &.. & 22.9 & 98.3 & $\begin{array}{l}. . \\
.\end{array}$ & 45.4 \\
\hline Venezuela & 9.2 & 13.4 & 95.0 & 89.9 & .. & 77.9 & 92.0 & 7.3 & 41.8 & .. & 32.0 & .. & 2.8 & 16.8 & 52.9 & .. & 60.0 \\
\hline \multicolumn{18}{|c|}{ West and Central Africa } \\
\hline Cameroon & 24.0 & 31.7 & 596.0 & 92.0 & 3.0 & 52.7 & 22.2 & 4.5 & 26.6 & 3.0 & 37.8 & 3.0 & .. & 6.8 & 39.8 & 2.5 & 25.0 \\
\hline Central African Rep. & 66.3 & 40.7 & 882.0 & 70.6 & 2.5 & 54.4 & 3.1 & 6.4 & 16.0 & 2.0 & 93.3 & 2.5 & .. & 0.0 & 35.6 & 2.5 & 4.0 \\
\hline Côte d'Ivoire & 27.9 & 29.6 & 645.0 & 79.3 & 3.0 & 68.8 & 36.5 & 9.2 & 30.8 & 3.0 & 56.0 & 3.0 & 2.5 & 2.1 & 32.7 & 3.0 & 26.5 \\
\hline Congo, Dem. Rep. & 77.1 & 42.6 & 693.0 & 35.4 & 2.5 & 31.2 & 0.4 & 3.6 & 33.5 & 2.5 & 74.8 & 3.0 & .. & 4.3 & 67.3 & 2.0 & 6.2 \\
\hline Congo, Rep. & 37.0 & 21.2 & 442.0 & 91.4 & 3.0 & 40.0 & 10.4 & 11.4 & 50.2 & 2.5 & 46.9 & 2.5 & .. & 33.6 & 65.4 & 2.0 & 8.1 \\
\hline Equatorial Guinea & .. & 26.2 & 342.0 & 55.7 & .. & 31.5 & 44.8 & 6.7 & 50.8 & .. & 66.2 & .. & .. & 2.7 & 55.9 & .. & 23.8 \\
\hline Gabon & 8.0 & 17.5 & 291.0 & & .. & 66.7 & 42.3 & 18.5 & 47.9 &.. & 37.0 & .. & .. & 9.3 & 89.3 & .. & 48.1 \\
\hline Ghana & 13.6 & 18.7 & 319.0 & 87.4 & 4.0 & 84.0 & 63.0 & 5.8 & 28.2 & 4.0 & 37.9 & 4.0 & 3.3 & 1.7 & 41.0 & 3.0 & 34.7 \\
\hline Liberia & 38.6 & 32.1 & 725.0 & 37.6 & 3.0 & 62.6 & 1.7 & 4.0 & 13.0 & 2.5 & 65.7 & 3.0 & .. & 2.0 & 43.4 & 3.0 & 7.3 \\
\hline \multicolumn{18}{|c|}{ Southeast Asia } \\
\hline Cambodia & .. & 33.5 & 161.0 & 94.9 & 4.0 & 69.1 & 49.2 & 0.3 & 31.7 & 2.5 & 55.1 & 3.0 & .. & 0.5 & 53.6 & 2.0 & 25.6 \\
\hline Indonesia & 6.8 & 36.4 & 126.0 & 89.7 & .. & 79.5 & 94.3 & 5.6 & 40.8 & .. & 21.8 & .. & 3.3 & 5.8 & 50.2 & .. & 25.4 \\
\hline Laos & 22.7 & 43.8 & 197.0 & 92.7 & 4.0 & 69.4 & 68.1 & 1.5 & 32.5 & 2.5 & 31.4 & 3.5 & 2.3 & 0.0 & 81.3 & 2.5 & 21.9 \\
\hline Malaysia & 0.3 & 17.2 & 40.0 & 98.1 & & 93.0 & 100.0 & 3.4 & 38.3 & .. & & .. & 3.8 & 2.3 & 67.6 & & 78.8 \\
\hline Myanmar & 6.5 & 35.1 & 178.0 & 94.5 & 3.0 & 74.4 & 49.0 & 0.8 & 35.0 & 2.5 & 41.0 & 2.5 & .. & 0.2 & 44.5 & 3.0 & 25.1 \\
\hline Papua New Guinea & 38.0 & 49.5 & 215.0 & 86.0 & 2.5 & 32.8 & 11.9 & 2.6 & 33.7 & 2.5 & .. & 2.0 & .. & 0.4 & 74.1 & 3.0 & 9.6 \\
\hline Philippines & 8.3 & 30.3 & 114.0 & 96.0 & & 90.3 & 82.5 & 5.7 & 30.8 & .. & 38.3 & .. & .. & 2.5 & 27.0 & .. & 55.5 \\
\hline Vietnam & 2.8 & 23.3 & 54.0 & 98.0 & 4.5 & 96.9 & 98.9 & 2.2 & 36.4 & 3.5 & 27.2 & 4.0 & .. & 1.8 & 47.6 & 3.0 & 46.5 \\
\hline
\end{tabular}

SDG1: No poverty. Indicator: Poverty headcount ratio at \$1.90 a day (2011 PPP) (\% of population). Data from the period 2005-2016, and for Guyana and Suriname from 1998 and 1999, respectively. SDG2: No hunger. Indicator: Prevalence of stunting, height for age (\% of children under 5). Data from the period 2006-2015. SDG3: Good health and well-being. Indicator: Maternal mortality ratio (modeled estimate, per 100,000 live births). 2015 data. SDG4: Quality education. Indicator: School enrollment, primary (\% net). Data mostly from 2014 
with some figures from the period 2012-2015, and for Democratic Republic of the Congo from 1999. SDG5: Gender equality. Indicator: CPIA gender equality rating ( $1=$ low to 6 high). 2016 data, except for Bolivia and Vietnam with 2015 data. SDG6: Clean water and sanitation. Indicator: Improved water source, rural (\% of rural population with access). 2016 data. SDG7: Affordable and clean energy. Indicator: Access to electricity, rural (\% of rural population). 2014 data. SDG8: Decent work and economic growth. Indicator: Unemployment, total (\% of total labor force) (modeled ILO estimate). 2017 data. SDG9: Industry, innovation and infrastructure. Indicator: Industry, value added (\% of GDP). 2016 data, except for Venezuela and Papua New Guinea with 2014 data. SDG10: Reduced inequalities. Indicator: CPIA social protection rating $(1=$ low to $6=$ high). 2016 data, except for Bolivia and Vietnam with 2015 data. SDG11: Sustainable cities and communities. Indicator: Population living in slums (\% of urban population). 2014 data, except for Venezuela with 2005 data. SDG12: Responsible consumption and production. Indicator: CPIA policy and institutions for environmental sustainability rating $(1=$ low to $6=$ high). 2016 data, except for Bolivia and Vietnam with 2015 data. SDG13: Climate action. Indicator: Disaster risk reduction progress score (1-5 scale; $5=$ best). 2011 data. SDG14: Life below water. Indicator: Marine protected areas (\% of territorial waters). 2014 data. SDG15: Life on land. Indicator: Forest area (\% of land area). 2015 data. SDG16: Peace, justice and strong institutions. Indicator: CPIA transparency, accountability, and corruption in the public sector rating ( $1=$ low to $6=$ high). 2016 data, except for Bolivia and Vietnam with 2015 data. SDG17: Partnerships for goals. Indicator: Individuals using the Internet (\% of population). 2016 data. Two dots (..) denotes no data available. 
Table 2. Forest and industrial forest concession areas (in 1000s ha) in 24 forest-rich tropical countries. Source: adapted from van Hensbergen [3].

\begin{tabular}{|c|c|c|c|c|c|c|}
\hline Region & $\begin{array}{l}\text { Total } \\
\text { Forest } \\
\text { Area }\end{array}$ & $\begin{array}{c}\text { Public } \\
\text { Forests } \\
\text { Area }\end{array}$ & $\begin{array}{c}\text { Public } \\
\text { Production } \\
\text { Forests Area }\end{array}$ & $\begin{array}{l}\% \text { of Public } \\
\text { Forests for } \\
\text { Production }\end{array}$ & $\begin{array}{c}\text { Industrial } \\
\text { Forest } \\
\text { Concessions } \\
\text { Area }\end{array}$ & $\begin{array}{c}\% \text { of Public } \\
\text { Production Forests } \\
\text { under Industrial } \\
\text { Forest Concessions }\end{array}$ \\
\hline $\begin{array}{c}\text { Latin } \\
\text { America }\end{array}$ & 718,820 & 425,368 & 43,582 & $10 \%$ & 18,597 & $43 \%$ \\
\hline $\begin{array}{l}\text { West and } \\
\text { Central } \\
\text { Africa }^{2}\end{array}$ & 262,365 & 260,227 & 68,173 & $26 \%$ & 56,114 & $82 \%$ \\
\hline $\begin{array}{c}\text { Southeast } \\
\text { Asia }^{3}\end{array}$ & 222,694 & 180,909 & 114,920 & $52 \%$ & 48,122 & $42 \%$ \\
\hline Total & $1,203,879$ & 866,503 & 226,675 & $19 \%$ & 122,833 & $54 \%$ \\
\hline
\end{tabular}

\section{Data Collection and Analysis}

The main part of data collection for the present study was done during the development of Voluntary Guidelines for forest concessions in the tropics (VG FC) [31]. This study builds on four sources of data: (i) literature review, (ii) multilingual online survey, (iii) semi-structured interviews and (iv) stakeholder consultation in selected countries. This mixed methods approach enables taking advantage of different sources of data and allows triangulation between them [35].

First, the literature review included scientific and grey literature (e.g., reports and policy updates) on forest concessions, SFM and forest governance in the tropics. The results of the literature review were used to develop the online survey and an interview protocol. A snowball approach [36] was employed to identify respondents for the online survey and expert interviews.

Second, the multilingual survey (English, French and Spanish) was implemented using QuestionPro during April and May 2017. The survey consisted of close-ended questions, with options for respondents to provide open-text comments and suggestions. The questions invited respondents to rate (on a five-point Likert scale (not important-slightly important-neutral-important-very important)) different predefined barriers hindering the potential contributions of forest concessions to the SDGs.

In total, the survey invitation was sent to 378 respondents, of whom 71 completed the survey resulting in a response rate of $19 \%$. The respondents were from international organizations, the private sector including forest industry, research and academia, civil society organizations and governmental organizations, and they represented the three tropical regions.

Third, the semi-structured interviews were conducted during April-June 2017 to complement and refine the data from the online survey. The interviews included open-ended questions regarding forest concessions' potential contributions to the SDGs and key barriers. The interviewees had different backgrounds, including policy makers, forest concession entrepreneurs, international organizations and research, and they represented the three tropical regions. In total, 20 experts were interviewed.

Fourth, stakeholder consultations were held as part of the preparation of the VG FC by the UN Food and Agriculture Organization (FAO), the World Bank and the European Forest Institute (EFI) [31] in (i) Libreville, Gabon, (ii) Maputo, Mozambique, (iii) Jakarta, Indonesia and (iv) Lima, Peru during June-July 2017. The participants comprised national and regional stakeholders from governments, local communities, concessionaires, civil society, the financial sector and technical experts.

To assess the potential contributions of forest concessions to the SDGs, the different SDGs and their targets were considered in analyzing forest concessions' support to implement them. A strength of the SDGs is that the targets are accompanied by universal indicators that enable measuring progress in their implementation. Hence, forest concessions' ability to support positive change in the SDG indicators 
was specifically assessed. Whether or not achieving SDGs/targets contributes to the sustainability of forest concessions was not assessed.

\section{Results}

The results of this study are presented in three sections: (1) pathways for forest concession to support the implementation of the SDGs; (2) region-specific barriers hindering the potential contribution of forest concessions to the SDGs; and (3) differences and similarities between West and Central Africa, Latin America and Southeast Asia. For more information on the potential contributions of forest concessions to support the implementation of the SDGs, see Appendix A.

\subsection{Pathways for Forest Concessions to Support the Implementation of the SDGs}

The ability of forest concessions to support the implementation of the SDGs might not be evident immediately, but it becomes more visible when considering the socioeconomic importance of forests and the forestry sector in tropical countries. In the tropics, the formal forestry sector represented US\$ 54 billion worth of gross value-added in general in 2011 [37]. At least 1.3 million people found formal employment in forestry in 2010 [37] - a figure that could exceed 5 million when multiplied by three or 3.5 to include informal employment, as suggested by the International Labour Organization [38] and Lescuyer and Cerutti [39] (Table 3). However, applying the multiplier of three or 3.5 should be taken as indicative, and can be an underestimation, considering the upsurge of informality in natural resource sector, particularly in Central Africa [40]. Additionally, $12 \%-22 \%$ of the total population in the three tropical regions are estimated to be in some way forest-dependent [41].

Table 3. Forestry value and employment in the tropics, and forest-dependence of population.

\begin{tabular}{|c|c|c|c|c|}
\hline Region & $\begin{array}{c}\text { Gross Value-Added in } \\
\text { the Formal Forestry } \\
\text { Sector in 2011 } \\
\text { (Billion USD) [37] }\end{array}$ & $\begin{array}{l}\text { People Employed } \\
\text { Formally in } \\
\text { Forestry in } 2010 \\
\text { (1000 FTE) d }\end{array}$ & $\begin{array}{l}\text { People Employed Formally } \\
\text { and Informally (1000) } \\
\text { (Formal Employment } \\
\text { Multiplied by Three) }\end{array}$ & $\begin{array}{c}\% \text { of Population } \\
\text { Dependent on } \\
\text { Forest }{ }^{f}[41]\end{array}$ \\
\hline Latin America $^{a}$ & 26,327 & 644 & 2576 & $0.7-9.8$ \\
\hline $\begin{array}{l}\text { West and Central } \\
\text { Africa } b\end{array}$ & 3283 & 93 & 372 & $20.5-23.0$ \\
\hline Southeast Asia $^{c}$ & 24,323 & 580 & 2320 & $14.2-32.3$ \\
\hline Total & 53,933 & 1317 & 5268 & $11.8-21.7$ \\
\hline
\end{tabular}

${ }^{a}$ Bolivia, Brazil, Guatemala, Guyana, Peru, Suriname and Venezuela. ${ }^{\mathrm{b}}$ Cameroon, Central African Republic, Côte d'Ivoire, Democratic Republic of the Congo, Equatorial Guinea, Gabon, Ghana, Liberia and Republic of the Congo. ' Cambodia, Indonesia, Laos, Malaysia, Myanmar, Papua New Guinea, Philippines and Vietnam.

${ }^{\mathrm{d}}$ Data for Democratic Republic of the Congo, Republic of the Congo and Laos from 2011. ${ }^{\mathrm{e}}$ Total population from World Development Indicators for 2010. ${ }^{\mathrm{f}}$ The figures given are only indicative rough estimates due to poor data availability and definitional ambiguities. FTE denotes full time equivalent.

Besides the direct contribution to value added and employment, forest concessions play a role in the provision of social infrastructure. A majority of the tropical countries listed in Table 3 are low-income or lower-middle-income countries [42]. As governments of these countries struggle to address challenges of sustainability (Table 1), business and industry in the tropics are called on to make further contributions towards sustainable development [43]. In this context, forest concessions, which are often located in remote areas characterized by weak socioeconomic development, particularly in terms of education, healthcare and economic opportunities, need to adapt their activities to address the local socioeconomic context and challenges.

The analysis of how forest concessions can make positive contributions to the SDGs revealed three broad pathways along which the potential contributions can take place: (i) sustainable use and management of ecosystem goods and services as the core business, (ii) provision of public goods for socioeconomic development; and (iii) contribution to (sub) national economies through income, employment and fiscal obligations. These pathways are not mutually exclusive but complementary. 
The identification of the pathways was inspired by the authors' and other recent work [37,44] leading to categorization and interpretation of forest concessions' contribution to individual SDGs along the pillars of sustainable development. Hence, the pathways can be considered in the wider context of environmental, social and economic sustainability. The first pathway mainly corresponds to the environmental dimension of sustainability, the second to the social dimension and the third to the economic dimension. The pathways show the expectations of how forest concessions can and should play a significant role in promoting and supporting the delivery of the SDGs.

\section{Pathway 1: Sustainable use and management of ecosystem goods and services as the core business}

The first pathway-SFM as the core business-could be understood as raison d'être for forest concessions, as forest concessions function as policy instruments for sustainable forest management (SFM). Accordingly, SFM should be contractually required and expected from concessions. Through this pathway, forest concessions can support the implementation of SDGs 6, 12, 13 and 15.

The main contribution of a sustainable forest concession in the tropics is to SDG 15, particularly to indicators 15.1.1 (forest cover as proportion of land), 15.2.1 (progress towards SFM) and 15.7.1 (proportion of traded wildlife that was poached or illicitly trafficked). Concessions can directly contribute to SDG 15 in three ways: (i) by increasing the value of standing forests and the opportunity cost of deforestation through SFM (see also [13,45]); (ii) by mainstreaming SFM in vast tracts of forest, thereby increasing the share of forest area under a forest management plan, including the proportion of forest area certified under independent forest certification schemes [3]; and (iii) by providing necessary capacities to establish Chains of Custody that assure legality of production vis-à-vis national and international requirements, such as those of the Convention on International Trade in Endangered Species of Wild Fauna and Flora $[46,47]$.

SDG 6 calls for universal access to drinking water along with protecting and restoring water related ecosystems. Forest concessions can make a positive contribution to this by minimizing the negative impacts of harvesting operations on water access and by employing appropriate restoration techniques as required by the concession contract and national legislation [13,45]. Likewise, concessionaires can ensure that all employees have access to clean drinking water and adequate toilets in the workplace. Moreover, by enhancing the resilience and adaptive capacities to climate change through improved implementation of forest management plans, ecosystem restoration, reduced impact logging techniques and silvicultural practices [31,48], forest concessions can make a positive contribution to SDG 13, which calls for taking urgent action to combat climate change and its impacts.

SDG 12 calls for ensuring sustainable production and consumption patterns. Forest concessions, by adopting sustainable practices throughout forest value chains, repurposing waste and publishing sustainability reports, positively contribute to SDG12. The allocation of management and use rights through long-term forest concession contracts leads to implementing practices towards more efficient use of the natural resources. This is particularly important considering the vast extent of industrial forest concessions, covering at least 122 million ha of tropical forests. Adopting sustainable management practices throughout these vast forest areas has considerable implications for sustainable production and provision of socioeconomic benefits from global forest resources [4-7]. Forest concessionaires can also increase the repurposing of waste to improve sustainable consumption. For instance, the logging company Congolaise Industrielle des Bois produces $4 \mathrm{MW}$ of electricity from sawmill wood waste. Furthermore, forest concessions usually have legal obligations to conduct social and environmental impact assessments to evaluate the expected or desired impacts from their operations. Concessionaires report on the sustainability impacts-be it on socioeconomic or environmental aspects - as part of Corporate Social Responsibility to inform investors and other interested stakeholders. 


\section{Pathway 2: Provision of public goods for socioeconomic development}

The second pathway includes a mix of legally required and voluntary contributions to provide public goods in remote forest areas where forest concessions are usually located. Such contributions can include basic services and infrastructure related to employment opportunities, health, education, road access or electricity. Together, these contributions can catalyze progress towards SDGs 1, 2, 3, 4, 7, 8 and 9.

Forest concessions can help alleviate poverty (SDG 1) and end hunger (SDG 2) through (i) job creation in remote areas with few economic activities [18,49]; (ii) provision of agricultural extension services and improved farming inputs and techniques, including agroforestry practices, to local communities [14,50]; and (iii) payment of taxes and royalties which enable the development of essential social and economic infrastructure. For example, in the Congo Basin concessionaires have established agroforestry areas in forest concessions for local communities, facilitated local communities' access to cattle for rearing and provided local communities with cocoa seedlings to support the diversification of their economic activities [14,50]. Similarly, concessions can contribute to SDG 3 through provision of healthcare services and facilities for workers and extension of workforce health and wellbeing programs to contractors and the local community at large [51-53].

Forest concessions can make a positive contribution to ensuring quality education (SDG 4) by building schools to provide educational services to communities living in or around a concession area $[51,54,55]$, recruiting locally where practicable to strengthen the local economic benefits and training workforce in technical and management skills. Furthermore, forest concessions can support the implementation of SDG 7, i.e., affordable and clean energy. For instance, in 2015, the logging company Congolaise Industrielle des Bois invested in a co-generation plant that uses wood waste at its concession in the Republic of the Congo, which produces 4 MW of electricity [50].

SDG 8 calls for sustainable economic growth, productive employment and a decent work force. Concessions can contribute to this through direct employment and strengthening economic development by adding value to forestry through vertical integration and integrating local enterprises into the value chain of products and services from the concession. Likewise, forest concessions require substantial infrastructure investments in order to develop, operate and transport timber and wood products. Especially when concessions operate in remote areas in countries with a large infrastructure financing gap, they often build and maintain road networks $[14,49,53]$. By so doing, concessions can make positive contributions to SDG 9. For instance, in Cambodia, concessions helped construct bridges and roads in community areas [53].

\section{Pathway 3: Contribution to (sub)national economies through income, employment and fiscal obligations}

The third pathway is related to legally required financial contributions made through different forest taxes, royalties, levies, fees and charges constituting the forest revenue system, as well as the payments to suppliers and labour. With this, rural economies are activated and developed by the backward and forward economic linkages generated by concessions' consumption and spending, while the government of a tropical country aims to capture an economic rent and generate revenue for (sub)national level. Export taxes for products from concessions can also help earn foreign currency. These contributions can enhance the financial capacity of the governments to make progress towards any SDG, in particular to fund activities to support protected forest areas and ecosystem services. Furthermore, the economic contribution from forest concessions can increase the opportunity cost of deforestation and buy in local support to keep forests standing.

\subsection{Existing Barriers}

Figure 1 presents a summary of region-specific barriers impeding the potential contributions of forest concessions to the SDGs. 


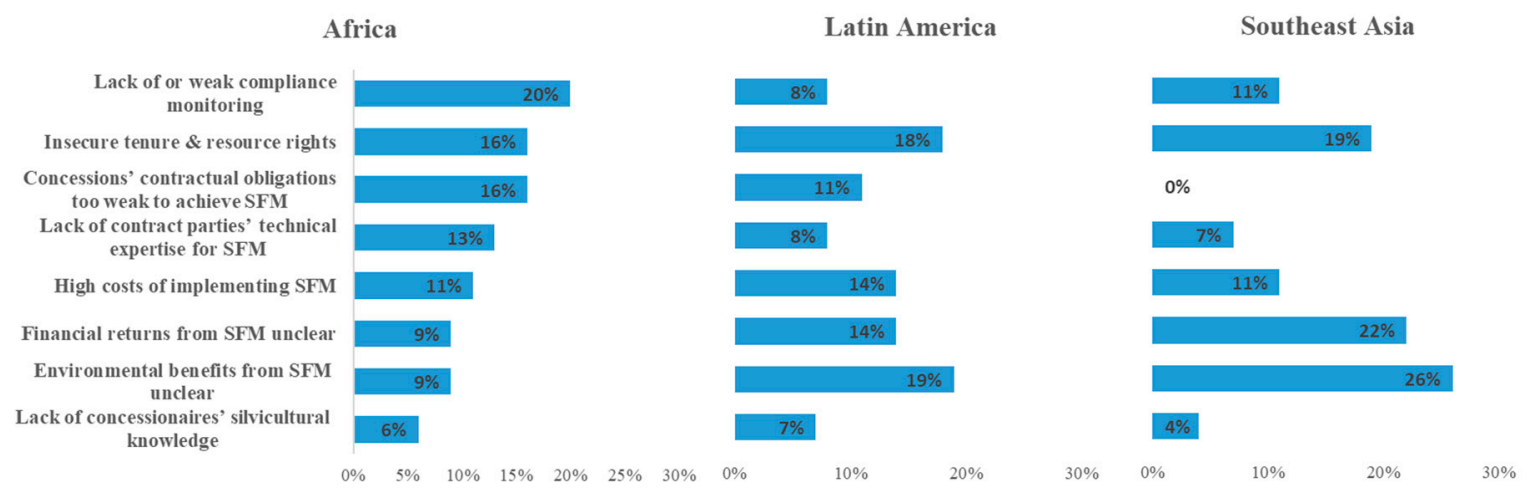

Figure 1. Summary of the opinions of online survey respondents on factors hindering the potential contributions of forest concessions to the SDGs.

\subsubsection{West and Central Africa}

Twenty percent of the online survey respondents identified the lack of or weak compliance monitoring of forest management plans and contractual obligations as a top impeding factor for effective contributions of forest concessions to the SDGs. This observation resonates with that of the participants of stakeholder consultations who identified weak enforcement and monitoring among the top challenges hindering the performance of forest concessions in the region. An interviewee from an international organization also noted that "weak monitoring and enforcement capacity of forest administrations in the region has resulted in illegal or informal logging inside and outside concessions, affecting the market competitiveness of legal timber and compromising forests' environmental sustainability".

Insecure tenure and resource rights (including overlapping titles and permits) and concessions' contractual obligations being insufficient to achieve SFM were both selected by $16 \%$ of the respondents. Participants of stakeholder consultations stated that tenure insecurity and overlapping titles are mainly a result of the lack of national land-use planning and cross-sectorial coordination, among other things. An interviewee from the private sector noted that: "concessionaires are being asked to adopt premium linked practices and to conduct environmental assessments, but at the same time most governments in the region are giving titles to competing users (e.g., mining and agroindustry) in same concession area. There is no guarantee of tomorrow, hence no sustainability". Along the same lines, Karsenty and Ferron [56] reported that different sectors in the region have been providing overlapping permits due to demographic pressures and noted the will of governments in the region to develop agribusiness on the model of Southeast Asia.

The lack of technical capacity for SFM (13\%) and high costs of implementing SFM plans and practices were also identified as important barriers. This perception of survey respondents corroborates with similar findings by Connolly [57]. Participants of stakeholder consultations in the three tropical regions also reported that the lack of skilled and trained experts in forest administration and the private sector is a powerful barrier affecting the implementation of forest management plans and concession contracts. Unclear financial returns and environmental benefits from SFM were both chosen by $9 \%$ of the survey respondents. The lack of concessionaires' silvicultural knowledge, including awareness and knowledge on multiple uses $(6 \%)$, was another barrier.

Finally, additional barriers mentioned during the expert interviews and stakeholder consultations in Africa included poor legal and institutional frameworks, high level of corruption and the lack of accountability and transparency in the planning, awarding and monitoring of concession contracts. An interviewee from an international organization mentioned that "it is a nightmare to fight illegal and informal forest activities in Central Africa as some political/economic elites are part of the complex network of corruption". These observations corroborate with similar findings by Tegegne et al. [58] and Tegegne [59]. 


\subsubsection{Latin America}

The factors most frequently reported by survey respondents impeding the positive contributions of forest concessions to the SDGs in Latin America included a lack of understanding of the timber industry regarding the environmental benefits (19\%), insecure tenure and resource rights (18\%) and high costs of implementing and unclear financial returns from SFM (14\%). An interviewee from a research organization asserted that "as long as forest concessions are focused on timber and disregard other ecosystem goods and services, it will be difficult to attain long-term sustainability in concessions. This requires a paradigm shift from a timber-focused management approach to a more holistic consideration and valuation of production forests and their multiple values." Concessions' insufficient contractual obligations to achieve SFM (11\%) was also identified as an important barrier.

The lack of technical capacity for SFM $(8 \%)$, the lack of or weak compliance monitoring $(8 \%)$, and the lack of concessionaires' silvicultural knowledge (7\%), including knowledge on diversification and promotion of new species, were selected as important impeding factors. On monitoring aspects, participants of the consultation in Lima, Peru, reported that poor implementation of efficient and credible monitoring systems with sanctions for non-compliance activities, and third-party monitoring and auditing is among the key factors limiting concessions' success in the region. The participants also stressed that significant work has to be done on the generation and dissemination of knowledge about the role and contributions of forest to mitigating climate change, food, water and energy. These observations corroborate with similar findings by Azevedo-Ramos et al. [17].

Additional barriers mentioned during the expert interviews and consultations included poor forest governance including corruption in granting concession contracts, ineffective government revenue collection mechanisms and the lack of long-term policies and development objectives for forest concession. Finally, an additional barrier suggested by survey respondents from private sector was unfair competition from informal or non-responsible producers, or from short-term concessions/permits, all of whom have less restrictions and environmental monitoring. In relation to this, a survey respondent from the private sector noted that: "If the state does not defend the forest against invaders, it tends to blame the concessionaire for deforestation."

\subsubsection{Southeast Asia}

Unclear environmental benefits (26\%) and financial returns (22\%) from SFM and insecure tenure and resource rights $(19 \%)$ were identified as top barriers hindering the potential contributions of forest concessions to the SDGs in Southeast Asia. The lack of long-term tenure security lowers the willingness concessionaires to invest in proper silvicultural and management practices. An interviewee from an international organization mentioned that "in many Southeast Asian countries, concession areas had been identified in a completely haphazard way, leading to identifying and granting concession in areas totally unsuited for sustainable concessions". High costs of implementing SFM plans and the lack of or weak compliance monitoring were both selected by $11 \%$ of the respondents. Jakarta consultation participants reported that concession contract monitoring is major challenge in the region, and it is difficult to deal with large companies with a lot of resources and influence. Furthermore, the lack of technical capacity for SFM (7\%) was identified as an important barrier. Similarly, the consultation participants reported that the demand for professional, trained and skilled personnel for implementing and monitoring sustainable forest management plans is enormous in the region [see also 19]. "Most forestry schools only teach about timber, so concepts like Payment for Ecosystem Services and multiple-use forest management fall outside of students' knowledge" as an interviewee from international organization noted. Finally, $4 \%$ of the respondent identified the lack of concessionaires' silvicultural knowledge, including product diversification, as a barrier. No respondent chose insufficient concessions' contractual obligations to achieve SFM as a barrier.

Finally, an additional barrier mentioned in the survey and interviews was the issue of subcontracting in Southeast Asia. The observation of respondents corroborate with similar findings by $[19,60]$, who reported that a forest concession is operated by a main contractor, who usually 
sub-contracts out individual tasks, such as harvesting, road construction, maintenance and log skidding. In this management arrangement, among others, oversight and accountability can be lost.

\subsection{Similarities and Differences between the Tropical Regions}

Our study clearly shows that there are similarities in terms of the perceived level of importance of various barriers hindering the potential contributions of forest concessions to the SDGs in West and Central Africa, Latin America and Southeast Asia. First, unclear and conflicting tenure rights, including the lack of integrated land-use planning, was cited by survey respondents, interviewees and participants of stakeholder consultations as the main barrier across the tropics. Recent studies also report that unclear resource and tenure rights has been the main challenge faced by the proponents of REDD+ [61] and forest landscape restoration [62-64]. Second, the participants of regional consultations consistently reported that the lack of qualified personnel at all levels within forest agencies and private companies is compromising the implementation of sustainable forest management plans and concession contracts. This observation corroborates with similar findings by Connolly [57] and Dlamini et al. [2]. Third, the lack of relevant tropical silvicultural knowledge was cited as the least important barrier in all three regions, indicating that the problem is rather effectively implementing appropriate silvicultural practices and forest management plans in a concession by concessionaires, as noted by an interviewee. Fourth, poor forest governance including competition with illegal production, corruption in granting concession contracts, ineffective government revenue collection mechanisms, weak compliance and monitoring and the lack of long-term policies and development objectives for forest concession were reported as important challenges in West and Central Africa, Asia and Latin America during regional consultations.

However, there are also differences between West and Central Africa, Asia and Latin America. Unclear financial returns from SFM was rated as a top barrier by online survey respondents in Southeast Asia and less so in Africa and Latin America. This observation of the respondents likely contradicts the relatively higher commercial potential of Southeast Asian forests compared to South American and African forests. In Borneo, first-entry harvest volumes in concessions can be between $50-80$ cubic meter per hectare; whereas in Brazil and Africa the average yield of commercial timber is 13 cubic meter per hectare and $4-5$ cubic meter per hectare respectively [3].

Similarly, concessions' insufficient contractual obligations to achieve SFM was rated as the most important barrier in West and Central Africa and Latin America, whereas no respondents considered it as a barrier in Southeast Asia. The lack of clarity and understanding about financial and environmental benefits from implementing SFM was rated as top barrier in Latin America and Southeast Asia, while it was less important in Africa.

\section{Discussion}

In this section, we (i) summarize the main findings; (ii) discuss the relationship between the three pathways, Voluntary Guidelines for forest concessions in the tropics (VG FC) [31] and the SDGs; and (iii) describe how broader efforts towards reaching the SDGs could enhance the sustainability of industrial forest concessions in forest rich countries.

The SDGs provide the most important framework for sustainable development of current time. Knowledge of the relationship between forests and the SDGs [6,26,44], and of the relationship between the SDGs and arrangements for SFM, such as community and smallholder forestry [27], has been increasing [65]. However, detailed understanding of how forest concessions can contribute to the SDGs has been unavailable until now for scientific and policy debates. Our analysis reveals that successful forest concessions can positively contribute to the achievement of 11 SDGs and 15 targets through three main pathways: (i) sustainable use and management of ecosystem goods and services as the core business (SDGs 6, 12, 13 and 15); (ii) provision of public goods for socioeconomic development (SDGs 1, 2, 3, 4, 7, 8 and 9); and (iii) contribution to (sub)national economies through income, employment and fiscal obligations (any SDG). Our analysis also reveals that these contributions 
depend on strong governance and an institutional framework that uses forest concessions as policy instruments to mainstream SFM. Tropical countries are, however, facing a number of barriers to ensure the positive contributions of forest concessions to the SDGs. Important governance challenges include insecure tenure and resource rights, the lack of transparency and accountability; corruption; weak and inconsistent regulatory frameworks and insufficient capacities to monitor and enforce laws and forestry regulations and collection of timber-related charges effectively. This observation corroborates with similar findings of Hatcher and Bailey [25], Azevedo-Ramos et al. [17] and Chan [19].

Building on lessons learned and experiences, the recent VG FC [31] has scrutinized factors leading to forest concessions' success and found eight principles, a set of guidelines and recommendations directed at specific stakeholders that, when taken together, will contribute to their success. These eight principles are:

1. Coherence with forest and forest-related policies for sustainable landscapes;

2. Clear, credible and effective legal and institutional frameworks;

3. Transparent, inclusive and accountable planning, allocation, implementation and monitoring of forest concessions;

4. Technical and human capacity for the management and operation of concession regimes at all levels;

5. Long-term economic and financial sustainability;

6. Clarity and security of tenure rights;

7. Community participation and social benefits to all;

8. Environmental integrity and sustainable use of forest resources.

Figure 2 maps the relationship among the eight principles, the three pathways and the SDGs. Authors argue that when proponents of forest concessions uphold these principles and put the guidelines thereunder into effect, it would help overcome the barriers uncovered in this study. This in turn would unlock the potential contributions of forest concessions to achieving the SDGs. The relationship among the principles, the pathways and the SDGs is briefly explained below, though not exhaustively.

The first pathway (sustainable use and management of ecosystem goods and services) is increasingly becoming a norm in the corporate world. The VG FC contains many principles, guidelines and recommendations in this area. Stakeholder specific recommendations mentioned in principles 1, 3 and 8 are relevant to this pathway. Upholding these recommendations could reinforce the contributions of forest concessions to SDGs 6, 12, 13 and 15. For instance, actions that encourage independent and voluntary certification (i.e., principle 3; Guideline 3.3) constitutes a direct contribution to SDG 15, since Indicator 15.2.1 incorporates the proportion of forest area under sustainable management plans as a subcomponent [31].

The second pathway concerns the provision of public goods for socioeconomic development. Forest concessions could more strongly contribute to this by following the set of recommendations contained in principles 4 to 8 . Implementing these recommendations could enhance the contributions of forest concessions to SDGs 1, 2, 3, 4, 7, 8 and 9. For instance, implementing the set of recommendations to strengthen local economies through financially and technically viable forest concessions (i.e., Principle 5; Guidelines 5.6) could support the ways in which concessions could deliver basic social services (SDG 1 and 2) and strengthen economic development by adding value to forestry through vertical integration, integrating local enterprises into the value chain of products and services from the concession (SDG 8). 


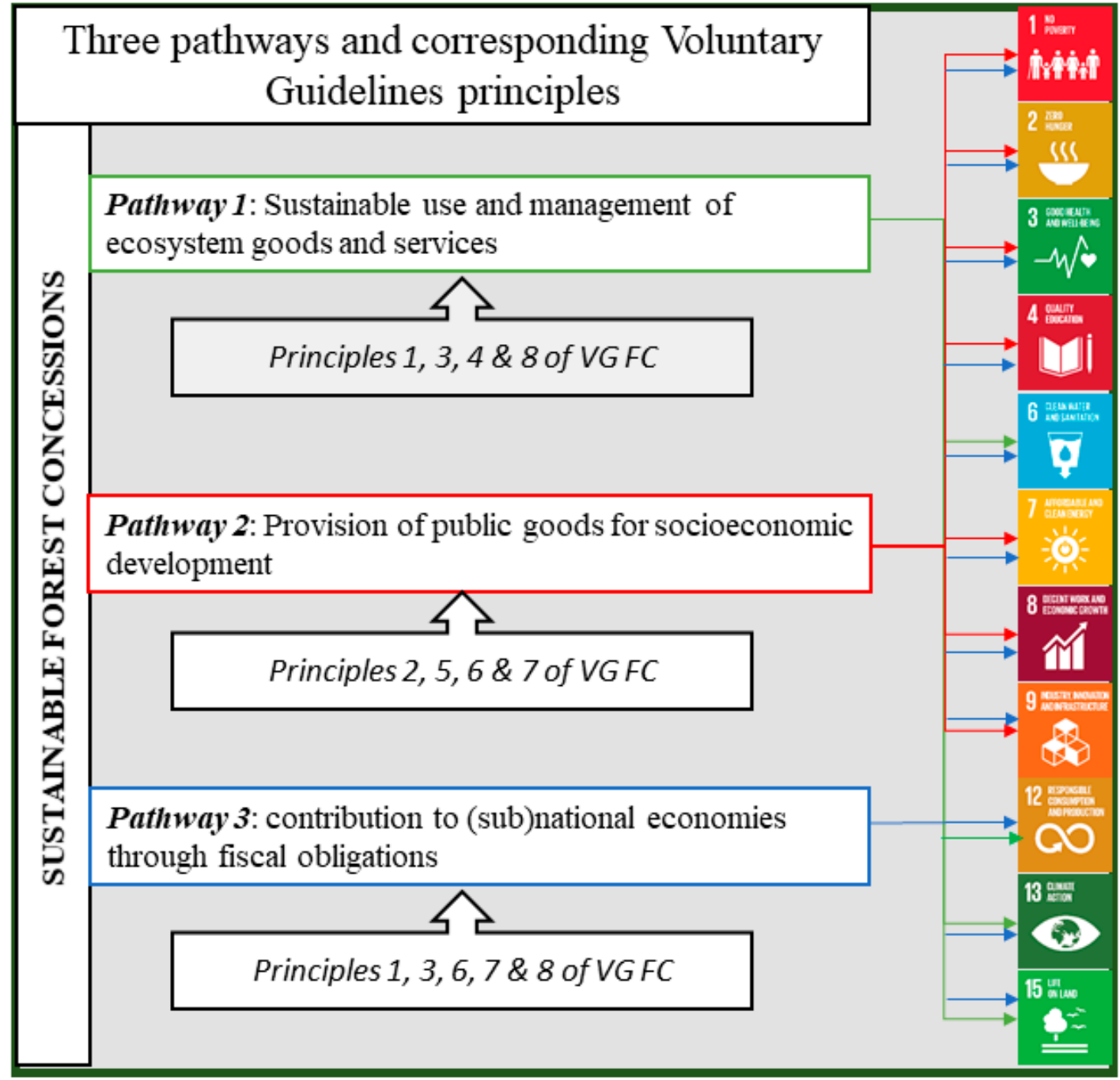

Figure 2. Pathways for forest concessions to contribute to the implementation of the SDGs, and links to the VG FC [31]. The three pathways show how forest concessions can contribute to the implementation of the SDGs. Under each pathway, the relevant principles of the VG FC are indicated that can help unlock forest concessions' potential contributions through the pathways.

The third pathway concerns contributions to national economies through taxation, royalties and other regulated monetary payments to state budgets. These contributions could be strengthened when relevant stakeholders, among others, (i) enhance the response of forest concessions to development goals through the adoption of a cross-sectoral approach (principle 1; Guideline 1.2); (ii) ensure competitive, transparent and inclusive awarding of concession contracts (principle 3; Guideline 3.2); and (iii) establish and apply mechanisms for effective and transparent revenue collection, reinvestment and benefit sharing (principle 5; Guideline 5.7). This can strengthen forest concessions' contribution to any SDG.

Furthermore, insecure tenure and resource rights - identified as a top barrier in all the tropical regions - could be addressed by following four guidelines and stakeholder-specific recommendations under principle six 'clarity and security of tenure rights' [31]. These guidelines include: (1) clarify and respect customary tenure rights in and near concessions; (2) develop and implement cooperation between private sector and community production; (3) design and implement community concessions to recognize customary tenure rights, where appropriate; and (4) develop and implement conflict resolution and compensation mechanisms. 
The Agenda 2030 and its SDGs are intended to guide and achieve transformational change in all segments of life and society. Implementing the SDGs requires multi-stakeholder collaboration across sectors, because the SDGs are, ultimately, interconnected and meant to be implemented by 'leaving no one behind' [66]. Authors argue that efforts towards reaching the SDGs support overcoming some of the barriers uncovered in this study, and this in turn would boost the contribution of forest concessions to the SDGs and their targets. For example, target 16.7 calls for ensuring responsive, inclusive, participatory and representative decision-making at all levels and target 17.14 for enhancing policy coherence for sustainable development. Both issues are relevant for and interlinked with effective land use planning, which is a pre-requisite for strengthening tenure security [31]. Thus, the implementation of these (and possibly other) SDGs and targets could be beneficial for the success of forest concession regimes.

It must be noted that the various contributions of forest concessions to the SDGs represent potentials. For example, the extent to which a forest concession should support the provision of essential healthcare services depends on a country's regulatory and governance frameworks as well as the performance of concessionaires. Along the same lines, authors argue that good governance and the clear use of the instrument to deliver such objectives as better planned and implemented concessions and binding concession contracts, are pivotal to forest concessions' sustainability. Thus, the results do not suggest that every forest concession would or could always support maximally and equally the implementation of all the identified SDG targets. Moreover, forest concessions can be seen as a double-edged sword: when well-managed and accompanied by supporting governance and institutional frameworks, they can benefit environment and people. When ill-managed and constrained by poor governance, concessions can degenerate the environment and marginalize local communities. Consequently, their sustainability is important for making progress towards the SDGs. Otherwise, they could be of detriment and work against these global goals.

\section{Conclusions and Recommendations}

This study reveals a strong relationship between the UN SDGs and forest concessions in tropical countries. Industrial forest concessions have the opportunity and potential to positively contribute to $12 \mathrm{SDGs}$ and corresponding targets. Therefore, tropical countries could take appropriate steps, e.g., inspired by VG FC, to align their forest concession regimes with the SDGs. Concessions can work for the SDGs if governments can acknowledge that this result can be incentivized through this contractual instrument and good governance. Progress on the overall SDG framework will also create enabling conditions for forest concessions to fulfill their potential contributions. Ultimately, the cross-sectoral and multi-stakeholder efforts to achieve the SDGs, which strengthens participation, transparency and accountability, among other things, are essential for the forest concessions' role in sustainable development

Considering the connections between forest concessions and the SDGs, the SDGs present a window of opportunity for understanding forest concessions as an instrument to mainstream SFM and raising their role of in (sub)national development strategies for sustainable development. The VG FC [31] provides principles and guidelines that-when respected and followed-can unlock the potential of forest concessions to contribute to the implementation of the SDGs and help overcome related barriers. Thus, the VG FC should be considered by governments, companies and other stakeholders in the design, implementation and administration of forest concessions.

Finally, this study's results invite further research on forest concession regimes' country and region-specific features, as such knowledge could better help in aligning them with the SDGs. For example, specific technical and financial challenges could have important implications for concessions' sustainability, which policy makers must be aware of and take into account in order to promote sustainability in their forest concession regimes. 
Author Contributions: Y.T.T., M.C., J.V.B. and T.L.-J. conceived and designed the methodological approach; Y.T.T. and T.L.-J. implemented regional workshops, Y.T.T. and M.C. analyzed the data; M.C., Y.T.T., and J.V.B. and T.L-J. wrote the paper; Y.T.T., M.C., J.V.B. and T.L.-J revised the draft manuscript.

Funding: This study was partly financed by the Federal Republic of Germany under agreement Forest 2015-4 "SFM approaches to foster FLEGT and REDD+ interactions (SAFARI)" and built on work funded by the Food and Agriculture Organization of the United Nations (FAO) (VC FC and stakeholder consultations) and the World Bank (stakeholder consultations).

Acknowledgments: The contents for this paper evolved from the work by the authors of this paper on the FAO Forestry Paper 180-Making forest concessions in the tropics work to achieve the 2030 Agenda: Voluntary Guidelines, developed by FAO and EFI. The content of this paper reflects only the authors' views and neither the implementing organizations (EFI and FAO), nor the funding organizations are liable for any use or interpretation that may be made of the information contained therein. We would like to acknowledge the numerous experts who have contributed to this study through interviews, online survey and participated in regional stakeholder consultations, and in particular the members of the Forest Concessions Initiative.

Conflicts of Interest: The authors declare no conflict of interest. The funder had no role in the design of the study; in the collection of, analyses, or interpretation of data; in the writing of the manuscript, and in the decision to publish the results.

\section{Appendix A}

The potential contributions of forest concessions to support the implementation of the SDGs. The indicators were selected based on forest concessions' ability to positively impact on them.

Table A1. The potential contributions of forest concessions to support the implementation of the United Nations SDGs.

\begin{tabular}{|c|c|c|c|}
\hline SDG Targets & SDG Indicators & Rationale for Support & Sources \\
\hline \multicolumn{4}{|c|}{ SDG 1 End poverty in all its forms everywhere } \\
\hline \multirow{2}{*}{$\begin{array}{l}1.2 \text { By } 2030 \text {, reduce at least by half } \\
\text { the proportion of men, women and } \\
\text { children of all ages living } \\
\text { in poverty }[\ldots]\end{array}$} & $\begin{array}{l}\text { 1.2.1 Proportion of population } \\
\text { living below the national } \\
\text { poverty line, by sex and age }\end{array}$ & \multirow{2}{*}{$\begin{array}{l}\text { Local communities can } \\
\text { benefit from direct payments } \\
\text { or other livelihood support } \\
\text { made by industrial forest } \\
\text { concessionaires. }\end{array}$} & \multirow[t]{2}{*}[14,67]{} \\
\hline & $\begin{array}{l}\text { 1.2.2 Proportion of men, women } \\
\text { and children of all ages living in } \\
\text { poverty in all its dimensions } \\
\text { according to national definitions }\end{array}$ & & \\
\hline
\end{tabular}

SDG 2 End hunger, achieve food security and improved nutrition and promote sustainable agriculture

2.3 By 2030, double the agricultural productivity and incomes of small-scale food producers [ ... ] including through secure and equal access to land, other productive resources and inputs, knowledge, financial services, markets and opportunities for value addition and non-farm employment

\subsubsection{Volume of production per} labour unit by classes of farming/pastoral/forestry enterprise size
Forest concessions can provide agricultural extension services and improved farming inputs and techniques, including agroforestry practices, to local communities.

SDG 3 Ensure healthy lives and promote well-being for all at all ages

3.8 Achieve universal health coverage, including financial risk protection, access to quality essential health-care services and access to safe, effective, quality and affordable essential medicines and vaccines for all

\subsubsection{Coverage of essential} health services [ ... ]
Forest concessions are often contractually obliged to provide healthcare services and facilities for workers, their families or the community at large. 
Table A1. Cont.

\begin{tabular}{|c|c|c|c|}
\hline SDG Targets & SDG Indicators & Rationale for Support & Sources \\
\hline \multicolumn{4}{|c|}{ SDG 4 Ensure inclusive and equitable quality education and promote lifelong learning opportunities for all } \\
\hline $\begin{array}{l}\text { 4.6 By 2030, ensure that all youth } \\
\text { and a substantial proportion of } \\
\text { adults, both men and women, } \\
\text { achieve literacy and numeracy }\end{array}$ & $\begin{array}{c}\text { 4.6.1 Percentage of population in } \\
\text { a given age group achieving at } \\
\text { least a fixed level of proficiency } \\
\text { in functional (a) literacy and (b) } \\
\text { numeracy skills, by sex }\end{array}$ & $\begin{array}{l}\text { Forest concessions often } \\
\text { construct schools and } \\
\text { provide education services } \\
\text { to community living in or } \\
\text { around concession area. }\end{array}$ & {$[51,54,55]$} \\
\hline \multicolumn{4}{|c|}{ SDG 6 Ensure availability and sustainable management of water and sanitation for all } \\
\hline $\begin{array}{l}\text { 6.6 By } 2020, \text { protect and restore } \\
\text { water-related ecosystems, } \\
\text { including }[\ldots] \text { forests }[\ldots]\end{array}$ & $\begin{array}{c}\text { 6.6.1 Change in the extent of } \\
\text { water-related ecosystems } \\
\text { over time }\end{array}$ & $\begin{array}{l}\text { Forest concessions can } \\
\text { maintain forest extent over } \\
\text { long-term by limiting } \\
\text { deforestation and forest } \\
\text { degradation. }\end{array}$ & {$[13,45]$} \\
\hline \multicolumn{4}{|c|}{ SDG 7 Ensure access to affordable, reliable, sustainable and modern energy for all } \\
\hline $\begin{array}{c}\text { 7.1 By 2030, ensure universal access } \\
\text { to affordable, reliable and modern } \\
\text { energy services }\end{array}$ & $\begin{array}{l}\text { 7.1.1 Proportion of population } \\
\text { with access to electricity }\end{array}$ & $\begin{array}{l}\text { Electricity is a service that } \\
\text { concessionaires may provide } \\
\text { to communities as part of } \\
\text { social obligations. }\end{array}$ & {$[68,69]$} \\
\hline $\begin{array}{c}\text { 7.2 By 2030, increase substantially } \\
\text { the share of renewable energy in } \\
\text { the global energy mix }\end{array}$ & & $\begin{array}{l}\text { Forest concessions can } \\
\text { facilitate access to } \\
\text { wood-based energy and use } \\
\text { wood residues for wood } \\
\text { energy generation. }\end{array}$ & {$[31,50]$} \\
\hline \multicolumn{4}{|c|}{$\begin{array}{c}\text { SDG } 8 \text { Promote sustained, inclusive and sustainable economic growth, full and productive employment and } \\
\text { decent work for all }\end{array}$} \\
\hline $\begin{array}{l}\text { 8.2 Achieve higher levels of } \\
\text { economic productivity through } \\
\text { diversification, technological } \\
\text { upgrading and innovation, } \\
\text { including through a focus on } \\
\text { high-value added and } \\
\text { labour-intensive sectors }\end{array}$ & & $\begin{array}{l}\text { Forest concessions can } \\
\text { strengthen economic } \\
\text { development by adding } \\
\text { value to forestry through } \\
\text { vertical integration and } \\
\text { integrating local enterprises } \\
\text { into the value chain of } \\
\text { products and services from } \\
\text { the concession. }\end{array}$ & {$[3,31]$} \\
\hline $\begin{array}{l}8.5 \text { By } 2030 \text {, achieve full and } \\
\text { productive employment and } \\
\text { decent work for all women and } \\
\text { men [ . . . ] }\end{array}$ & $\begin{array}{l}\text { 8.5.2 Unemployment rate, by } \\
\text { sex, age and persons with } \\
\text { disabilities }\end{array}$ & $\begin{array}{l}\text { Concessions provide } \\
\text { employment opportunities } \\
\text { in remote areas with few } \\
\text { economic opportunities. }\end{array}$ & {$[18,49]$} \\
\hline \multicolumn{4}{|c|}{ SDG 9 Build resilient infrastructure, promote inclusive and sustainable industrialization and foster innovation } \\
\hline $\begin{array}{l}\text { 9.1 Develop quality, reliable, } \\
\text { sustainable and resilient } \\
\text { infrastructure }[\ldots]\end{array}$ & $\begin{array}{l}\text { 9.1.1 Proportion of the rural } \\
\text { population who live within } 2 \\
\mathrm{~km} \text { of an all-season road }\end{array}$ & $\begin{array}{l}\text { Concessionaires often build } \\
\text { (and maintain) road } \\
\text { networks in remote areas. }\end{array}$ & {$[14,49,53]$} \\
\hline \multicolumn{4}{|c|}{ SDG 12 Ensure sustainable consumption and production patterns } \\
\hline $\begin{array}{l}\text { 12.6 Encourage companies, } \\
\text { especially large and transnational } \\
\text { companies, to adopt sustainable } \\
\text { practices and to integrate } \\
\text { sustainability information into } \\
\text { their reporting cycle }\end{array}$ & $\begin{array}{l}\text { 12.6.1 Number of companies } \\
\text { publishing sustainability reports }\end{array}$ & $\begin{array}{l}\text { Forest concessions are } \\
\text { embedded in complex } \\
\text { environmental and } \\
\text { socioeconomic contexts and } \\
\text { must assess and report on } \\
\text { their social and } \\
\text { environmental impacts. }\end{array}$ & $\begin{array}{l}{[1,55,68,} \\
\quad 70]\end{array}$ \\
\hline
\end{tabular}


Table A1. Cont.

\begin{tabular}{|c|c|c|c|}
\hline SDG Targets & SDG Indicators & Rationale for Support & Sources \\
\hline \multicolumn{4}{|c|}{ SDG 13 Take urgent action to combat climate change and its impacts } \\
\hline $\begin{array}{l}\text { 13.1 Strengthen resilience and } \\
\text { adaptive capacity to } \\
\text { climate-related hazards and } \\
\text { natural disasters in all countries }\end{array}$ & & $\begin{array}{l}\text { Forest concessions can } \\
\text { enhance the resilience and } \\
\text { adaptive capacities to } \\
\text { climate change through } \\
\text { forest management, } \\
\text { ecosystem restoration, } \\
\text { reduced impact logging } \\
\text { techniques and } \\
\text { silvicultural practices }\end{array}$ & {$[31,48]$} \\
\hline \multicolumn{4}{|c|}{$\begin{array}{l}\text { SDG } 15 \text { Protect, restore and promote sustainable use of terrestrial ecosystems, sustainably manage forests, } \\
\text { combat desertification, and halt and reverse land degradation and halt biodiversity loss }\end{array}$} \\
\hline $\begin{array}{c}15.1 \text { By } 2020 \text {, ensure the } \\
\text { conservation, restoration and } \\
\text { sustainable use of terrestrial and } \\
\text { inland freshwater ecosystems and } \\
\text { their services, in particular } \\
\text { forests [ . . . ] }\end{array}$ & $\begin{array}{l}\text { 15.1.1 Forest area as a } \\
\text { proportion of total land area }\end{array}$ & $\begin{array}{l}\text { Forest concessions can } \\
\text { maintain forest extent over } \\
\text { long-term by limiting } \\
\text { deforestation and } \\
\text { forest degradation. }\end{array}$ & {$[13,45]$} \\
\hline $\begin{array}{l}15.2 \text { By } 2020, \text { promote the } \\
\text { implementation of sustainable } \\
\text { management of all types of } \\
\text { forests }[\ldots]\end{array}$ & $\begin{array}{l}\text { 15.2.1 Progress towards } \\
\text { sustainable forest management }\end{array}$ & $\begin{array}{l}\text { Concessionaires can } \\
\text { contribute to SFM e.g., } \\
\text { through management plans } \\
\text { and adoption of } \\
\text { sustainability certification. }\end{array}$ & [3] \\
\hline $\begin{array}{c}15.7[\ldots \text { ] end poaching and } \\
\text { trafficking of protected species of } \\
\text { flora and fauna and address both } \\
\text { demand and supply of illegal } \\
\text { wildlife products }\end{array}$ & $\begin{array}{c}\text { 15.7.1 Proportion of traded } \\
\text { wildlife that was poached or } \\
\text { illicitly trafficked }\end{array}$ & $\begin{array}{l}\text { Forest concessions, through } \\
\text { implementation of a chain of } \\
\text { custody, can control illegal } \\
\text { harvest of and trade } \\
\text { in wood. }\end{array}$ & {$[46,47]$} \\
\hline
\end{tabular}

\section{References}

1. FAO. Governance Principles for Concessions and Contracts in Public Forests; FAO: Rome, Italy, 2001; ISBN 9251046123.

2. Dlamini, C.; Larwanou, M.; Chirwa, P.W. A brief overview of the capacities of public forest administrations in climate change work in the moist forests countries of Sub-Saharan Africa. Int. For. 2015, 17, 53-66. [CrossRef]

3. van Hensbergen, B. Forest Concessions_Past Present and Future? Forestry and Institutions Working Paper 36; FAO: Rome, Italy, 2016.

4. Bele, M.Y.; Sonwa, D.J.; Tiani, A.M. Adapting the Congo Basin forests management to climate change: Linkages among biodiversity, forest loss, and human well-being. For. Policy Econ. 2015, 50. [CrossRef]

5. Boyle, J.R.; Tappeiner, J.C.; Waring, R.H.; Tattersall Smith, C. Sustainable Forestry: Ecology and Silviculture for Resilient Forests; Elsevier Inc.: Amsterdam, The Netherlands, 2016; ISBN 978-0-12-409548-9.

6. Swamy, L.; Drazen, E.; Johnson, W.R.; Bukoski, J.J. The future of tropical forests under the United Nations Sustainable Development Goals. J. Sustain. For. 2017, 37, 221-256. [CrossRef]

7. Sasaki, N.; Chheng, K.; Ty, S. Managing production forests for timber production and carbon emission reductions under the REDD+ scheme. Environ. Sci. Policy 2012, 23, 35-44. [CrossRef]

8. Giudice, R.; Soares-Filho, B.S.; Merry, F.; Rodrigues, H.O.; Bowman, M. Timber concessions in Madre de Dios: Are they a good deal? Ecol. Econ. 2012, 77, 158-165. [CrossRef]

9. Gray, J.A. Forest Concession Policies and Revenue Systems-Country Experience and Policy Changes for Sustainable Tropical Forestry; World Bank: Washington, DC, USA, 2002; ISBN 0821351702.

10. Krelove, R.; Melhado, O. Forestry Taxation in Africa: The Cases of Liberia and Gabon. Int. For. Rev. 2010, 12, 139-149. [CrossRef]

11. Banerjee, O.; Alavalapati, J. Illicit exploitation of natural resources: The forest concessions in Brazil. J. Policy Model. 2010, 32, 488-504. [CrossRef] 
12. Brandt, J.S.; Nolte, C.; Agrawal, A. Deforestation and timber production in Congo after implementation of sustainable forest management policy. Land Use Policy 2016, 52, 15-22. [CrossRef]

13. Bruggeman, D.; Meyfroidt, P.; Lambin, E.F. Production forests as a conservation tool: Effectiveness of Cameroon's land use zoning policy. Land Use Policy 2015, 42, 151-164. [CrossRef]

14. Lescuyer, G.; Mvondo, S.A.; Essoungou, J.N.; Toison, V.; Trébuchon, J.F.; Fauvet, N. Logging concessions and local livelihoods in Cameroon: From indifference to alliance? Ecol. Soc. 2012, 17. [CrossRef]

15. Purnomo, H.; Mendoza, G. A system dynamics model for evaluating collaborative forest management: A case study in Indonesia. Int. J. Sustain. Dev. World Ecol. 2011, 18, 164-176. [CrossRef]

16. Ravikumar, A.; Andersson, K.; Mwangi, E.; Guariguata, M.R.; Nasi, R. Towards more equitable terms of cooperation: Local people's contribution to commercial timber concessions. Int. For. Rev. 2012, 14, 157-176. [CrossRef]

17. Azevedo-Ramos, C.; Silva, J.N.M.; Merry, F. The evolution of Brazilian forest concessions. Elem. Sci. Anthr. 2015, 3. [CrossRef]

18. Cerutti, P.O.; Poufoun, J.N.; Karsenty, A.; Eba ', R.; Atyi, A.; Nasi, R.; Fomete Nembot, T. The technical and political challenges of the industrial forest sector in Cameroon. Int. For. Rev. 2016, 18, 25-39. [CrossRef]

19. Chan, B. Southeast Asian Forest Concessions: Small steps forward. Int. For. Rev. 2016, 18, 27-35. [CrossRef]

20. Radachowsky, J.; Ramos, V.H.; McNab, R.; Baur, E.H.; Kazakov, N. Forest concessions in the Maya Biosphere Reserve, Guatemala: A decade later. For. Ecol. Manag. 2012, 268, 18-28. [CrossRef]

21. Edwards, D.P.; Tobias, J.A.; Sheil, D.; Meijaard, E.; Laurance, W.F. Maintaining ecosystem function and services in logged tropical forests. Trends Ecol. Evol. 2014, 29, 511-520. [CrossRef]

22. Karsenty, A.; Drigo, I.G.; Piketty, M.G.; Singer, B. Regulating industrial forest concessions in Central Africa and South America. For. Ecol. Manag. 2008, 256, 1498-1508. [CrossRef]

23. Cin Khai, T.; Mizoue, N.; Kajisa, T.; Ota, T.; Yoshida, S. Stand structure, composition and illegal logging in selectively logged production forests of Myanmar: Comparison of two compartments subject to different cutting frequency. Glob. Ecol. Conserv. 2016, 7, 132-140. [CrossRef]

24. McKenney, B. Questioning Sustainable Concession Forestry in Cambodia. Cambodia Dev. Rev. 2002, 6, 1-7.

25. Hatcher, J.; Bailey, L. Tropical Forest Tenure Assessment: Trends Challenges and Opportunities; 2010; Available online: http:/ / www.itto.int/direct/topics / topics_pdf_download/topics_id=2637\&no=0\&disp= inline (accessed on 7 January 2019).

26. Timko, J.; Le Billon, P.; Zerriffi, H.; Honey-Rosés, J.; de la Roche, I.; Gaston, C.; Sunderland, T.C.; Kozak, R.A. A policy nexus approach to forests and the SDGs: Tradeoffs and synergies. Curr. Opin. Environ. Sustain. 2018, 34, 7-12. [CrossRef]

27. de Jong, W.; Pokorny, B.; Katila, P.; Galloway, G.; Pacheco, P. Community Forestry and the Sustainable Development Goals: A Two Way Street. Forests 2018, 9, 331. [CrossRef]

28. Krott, M. The politics of forest bureaucracy as a subject of comparative studies. Silva Fenn. 1986, 20, $282-285$. [CrossRef]

29. Azarian, R. Potentials and limitations of comparative method in social science. Int. J. Humanit. Soc. Sci. 2011, 1, 113-125.

30. United Nations. Final List of Proposed Sustainable Development Goal Indicators; 2016; Available online: https: / / sustainabledevelopment.un.org/content/documents/11803Official-List-of-Proposed-SDG-Indicators.pdf (accessed on 7 January 2019).

31. Tegegne, Y.T.; Van Brusselen, J.; Cramm, M.; Linhares-Juvenal, T.; Pacheco, P.; Sabogal, C.; Tuomasjukka, D. Making Forest Concessions in the Tropics Work to Achieve the 2030 Agenda: Voluntary Guidelines; FAO Forestry Paper 180; FAO: Rome, Italy, 2018; ISBN 9789251305478.

32. Buergin, R. Ecosystem Restoration Concessions in Indonesia: Conflicts and Discourses. Crit. Asian Stud. 2016, 48, 278-301. [CrossRef]

33. Rice, R. Conservation Concessions-Concept Description. 2002. Available online: https://www.cbd.int/ financial/interdevinno/g-interdevconcession.pdf (accessed on 7 January 2019).

34. Sabogal, C.; Guariguata, M.R.; Broadhead, J.; Lescuyer, G.; Savilaakso, S.; Essoungou, J.N.; Sist, P. Multiple-Use Forest Management in the Humid Tropics: Opportunities and Challenges for Sustainable Forest Management; FAO Forestry Paper No. 173; FAO: Rome, Italy; CIFOR: Bogor, Indonesia, 2013; ISBN 9789251078235.

35. Olsen, W. Data Collection: Key Debates and Methods in Social Research; SAGE Publications: New Delhi, Indian, 2012. 
36. Miles, M.; Huberman, A. Qualitative Data Analysis: An Expanded Sourcebook, 2nd ed.; SAGE: Thousand Oaks, CA, USA, 1994.

37. Lebedys, A.; Li, Y. Contribution of the Forestry Sector to National Economies, 1990-2011; FAO: Rome, Italy, 2014.

38. International Labour Office. Decent Work in Forestry-Policy Guidance Notes; International Labour Office: Geneva, Switzerland, 2017.

39. Lescuyer, G.; Cerutti, P. Sustainable Forest Management Policies in Central Africa-Taking the Informal Sector into Account; Center for International Forestry Research: Paris, France, 2013.

40. International Labour Office. Women and Men in the Informal Economy: A Statistical Picture, 3rd ed.; ILO: Geneva, Switzerland, 2018; ISBN 978-92-2-131581-0.

41. Chao, S. Forest Peoples: Numbers Across the World; Forest Peoples Programme: Moreton-in-Marsh, UK, 2012.

42. World Bank. World Bank Country and Lending Groups. Available online: https://datahelpdesk. worldbank.org/knowledgebase/articles/906519-world-bank-country-and-lending-groups (accessed on 13 February 2018).

43. Veglio, F.; Fiedler, D. Delivering on the Sustainable Development Goals: The Inclusive Business Approach; World Business Council for Sustainable Development: Geneva, Switzerland, 2016; ISBN 978-2-940521-63-0.

44. FAO. The State of the World's Forests-Forest Pathaways to Sustainable Development; FAO: Rome, Italy, 2018; ISBN 9789251305614.

45. Ruslandi; Cropper, W.P.; Putz, F.E. Effects of silvicultural intensification on timber yields, carbon dynamics, and tree species composition in a dipterocarp forest in Kalimantan, Indonesia: An individual-tree-based model simulation. For. Ecol. Manag. 2017, 390, 104-118. [CrossRef]

46. Laporte, J.; Vandenhaute, M. Traceability-A Management Tool for Enterprises and Governments; FAO: Rome, Italy, 2016.

47. Kleinschmit, D.; Mansourian, S.; Wildburger, C.; Purret, A. (Eds.) Illegal Logging and Related Timber Trade-Dimensions, Drivers, Impacts and Responses; A Global Scientific Rapid Response Assessment Report; IUFRO: Vienna, Austria, 2016; Volume 35, ISBN 3901347240.

48. Long, A. REDD+, adaptation, and sustainable forest management: Toward effective polycentric global forest governance. Trop. Conserv. Sci. 2013, 6, 384-408. [CrossRef]

49. Singer, B.; Karsenty, A. Can concessions be justified? A multidisciplinary perspective from Africa and beyond. J. Sustain. For. 2008, 27, 224-245. [CrossRef]

50. Olam. Corporate Responsibility and Sustainability Report 2015; 2015; Available online: http: / / 49tmko49h46b4e0czy3rlqaye1b.wpengine.netdna-cdn.com/wp-content/uploads/2014/02/CorporateResponsibility-and-Sustainability-Report-2015-final.pdf (accessed on 7 January 2019).

51. Tomaselli, I.; Hirakuri, S.; Penno Saraiva, S. Increasing the competitiveness of the Brazilian forest sector. In Good Business: Making Private Investments Work for Tropical Forests; Asen, A., Savenije, H., Schmidt, F., Eds.; Tropenbos International: Wageningen, The Netherlands, 2012; pp. 40-50.

52. Karsenty, A. Overview of Industrial Forest Concessions and Concession-Based Industry in Central and West Africa, and Considerations of Alternatives. 2007. Available online: http://pfbc-cbfp.org/tl_ files/archive/thematique/Forest_Concessions_and_Concession_Industry_Central.pdf\%5Cnhttp: / / www.rightsandresources.org/documents/files/doc_131.pdf (accessed on 7 January 2019).

53. Prachvuthy, M. Land Acquisition by Non-Local Actors and Consequences for Local Development: Impacts of Economic Land Concessions on Livelihoods of Indigenous Communities in Northeastern Provinces of Cambodia. 2011. Available online: http:/ / www.landgovernance.org/assets/2014/07/Cambodia_landacquisition_impacts_ indigenouspeople.pdf (accessed on 7 January 2019).

54. Sabogal, C.; Casaza, J. (Eds.) Standing Tall: Exemplary Cases of Sustainable Forest Management in Latin America and the Caribbean; FAO: Rome, Italy, 2010; ISBN 9789251066775.

55. Subedi, S.P. Report of the Special Rapporteur on the Situation of Human Rights in Cambodia. Addendum. A human Rights Analysis of Economic and Other Land Concessions in Cambodia. 2012. Available online: https:/ / cambodia. ohchr.org/ \{\}cambodiaohchr/sites/default/files / news/WebDOCs/2012/SR_report_on_ELC_Eng.pdf (accessed on 7 January 2019).

56. Karsenty, A.; Ferron, C. Recent evolutions of forest concessions status and dynamics in Central Africa. Int. For. Rev. 2017, 19, 8-23. [CrossRef]

57. Connolly, C. Constraints to Sustainable Forest Management of Africa's Humid Forests: The ATIBT Experience. Int. For. Rev. 2006, 8, 78-82. [CrossRef] 
58. Tegegne, Y.T.; Ramcilovic-Suominen, S.; Fobissie, K.; Visseren-Hamakers, I.J.; Lindner, M.; Kanninen, M. Synergies among social safeguards in FLEGT and REDD+ in Cameroon. For. Policy Econ. 2017, 75, 1-11. [CrossRef]

59. Tegegne, Y.T. FLEGT and REDD+ synergies and impacts in the Congo Basin: lessons for global forest governance. Academic dissertation for the Dr. Sc. (Agric.EFor.) Degree; Viikki Tropical Resources Institute (VITRI): Helsinki, Finland, 2016; ISBN 978-951-51-2816-4.

60. Barr, C. Banking on Sustainability: Structural Adjustment and Forestry Reform in Post-Suharto Indonesia; WWF Macroeconomics Program Office/CIFOR: Washington, DC, USA, 2001.

61. Sunderlin, W.D.; Sassi, C.; Sills, E.O.; Duchelle, A.E.; Larson, A.; Resosudarmo, I.A.P.; Awono, A.; Kweka, D.; Huynh, T.B. Creating an appropriate tenure foundation for REDD+: The record to date and prospects for the future. World Dev. 2018, 106, 376-392. [CrossRef]

62. McLain, R.; Guariguata, M.R.; Lawry, S. Implementing Forest Landscape Restoration initiatives-Tenure, goverance, and equity considerations. Accelerating Restoration of Degraded Forest Landscapes: The Role of Tenure Security and Local Forest Governance in Catalyzing Global Restoration Initiatives. 2017. Available online: https: / /www.cifor.org/wp-content/uploads /2017/11/Implementing\%20FLR.pdf (accessed on 7 January 2019).

63. Guariguata, M.; Brancalion, P. Current challenges and perspectives for governing forest restoration. Forests 2014, 5, 3022-3030. [CrossRef]

64. Djenontin, I.N.S.; Foli, S.; Zulu, L.C. Revisiting the factors shaping outcomes for forest and landscape restoration in Sub-Saharan Africa: A way forward for policy, practice and research. Sustainability 2018, 10, 906. [CrossRef]

65. Katila, P.; de Jong, W.; Galloway, G.; Pokorny, B.; Pacheco, P. Building on Synergies: Harnessing Community and Smallholder Forestry for Sustainable Development Goals; IUFRO: Vienna, Austria, 2017; ISBN 9783902762757.

66. United Nations. Transforming Our World: The 2030 Agenda for Sustainable Development. 2015. Available online: http://www.un.org/en/development/desa/population/migration/generalassembly/ docs/globalcompact/A_RES_70_1_E.pdf (accessed on 7 January 2019).

67. World Bank. Rethinking Forest Partnerships and Benefit Sharing: Insights on Factors and Context that Make Collaborative Arrangements Work for Communities and Landowners; World Bank: Washington, DC, USA, 2009.

68. Topa, G.; Karsenty, A.; Megevand, C.; Debroux, L. The Rainforests of Cameroon: Experience and Evidence from a Decade of Reform; World Bank: Washington, DC, USA, 2009; ISBN 9780821378786.

69. Cerutti, P.O.; Lescuyer, G.; Tacconi, L.; Eba'a Atyi, R.; Essiane, E.; Nasi, R.; Tabi Eckebil, P.P.; Tsanga, R. Social impacts of the Forest Stewardship Council certification in the Congo basin. Int. For. Rev. 2017, 19. [CrossRef]

70. Cerutti, P.O.; Mbongo, M.; Vandenhaute, M. State of the Timber Sector in Cameroon (2015); FAO and CIFOR: Bogor, Indonesia, 2015.

(c) 2019 by the authors. Licensee MDPI, Basel, Switzerland. This article is an open access article distributed under the terms and conditions of the Creative Commons Attribution (CC BY) license (http://creativecommons.org/licenses/by/4.0/). 